IRA-International Journal of Management \& Social Sciences

ISSN 2455-2267; Vol.03, Issue 03 (2016)

Institute of Research Advances

http://research-advances.org/index.php/RAJMSS

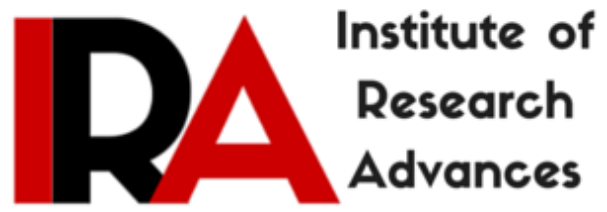

\title{
Digital Inclusion: A Tool for Empowerment
}

\author{
Dr. Neelam Kalla \\ Assistant Professor \\ Department of Management Studies \\ Jai Narain Vyas University, India.
}

DOI: http://dx.doi.org/10.21013/jmss.v3.n3.p26

\section{How to cite this paper:}

Kalla, N. (2016). Digital Inclusion: A Tool for Empowerment. IRA-International Journal of Management \& Social Sciences (ISSN 2455-2267), 3(3). doi:http://dx.doi.org/10.21013/jmss.v3.n3.p26

(C) Institute of Research Advances

\section{(cc) $\mathrm{EY}-\mathrm{NC}$}

This works is licensed under a Creative Commons Attribution-Non Commercial 4.0 International License subject to proper citation to the publication source of the work.

Disclaimer: The scholarly papers as reviewed and published by the Institute of Research Advances (IRA) are the views and opinions of their respective authors and are not the views or opinions of the IRA. The IRA disclaims of any harm or loss caused due to the published content to any party. 


ABSTRACT
In the contemporary picture there is conjoint consensus amongst all the policy
makers from across the sphere that devoid of ICT and digital inclusion; the growth of
an individual is stalled. Specially in developing economy like India, where poverty
eradication and employment generation are foremost objectives; digital inclusion is a
must. Considering factors like lack of infrastructure, primary education and
availability affordable technologies and others, the strategic intervention and
collaborative efforts by government and non-government organizations is
indispensable.
Present study provides an analysis of secondary data in order to investigate the
current status of digital inclusion and digital divide of Indian population. Further it
also illustrates the strategies to eradicate the digital divide and cites example from
successful digital inclusion campaigns from other parts of world.

Keywords: Digital Inclusion, Digital Empowerment, Digital Divide.

\section{Technology: Foundation for Human Development}

In the history of human civilization has always marked the significance of technology in ham life. Technology acts as a base for economic, social and political development of people. Technology has a deep rooted impact on human life, (Weil, M. M. (1995). There has always been a debate on empowering people through information and communication technologies (ICTs). The dark and bright sides' talks have always been the focal point for most of the discussions. But despite of all the arguments one has to agree with that ICT accessibility can lead to major social and economic development for all the sections including urban as well as rural populations, persons with disabilities along with women, youth, children and elderly people.

Specifically when it comes to rural area many of their indicators performing low can be attributed to low access to ICT in comparison their urban counterparts.

\section{The Digital Divide}

Though the latest researches show the potential for digital inclusion. According to Digital Inclusion Report 2014 there are, with 3.6 billion unique mobile subscribers and 7.2 billion connections globally. So mobiles as tools for personal technology show the rising indicators of technological inclusion of people. It shows that how ICT has changed life of almost half of the population on earth from simply allowing people to communicate with each other, to enabling them to access services such as education, healthcare and financial services. (Digital Inclusion Report 2014). But still the inclusion of a major part of population remains a challenge.

As according to report of ITU, $40 \%$ of the world's population are still unconnected and out of them rural population counts for 64\%. (McKinsey and Company). Especially in India according to the Brookings Financial and Digital Inclusion Project Report, 2015; the adult population in India is 888 million and the individual mobile subscribers are only $37 \%$. In the network readiness index India still ranks as low as 83 (World Economic Forum Report, 2014). So this gap shows that still there is a major chunk of population which is away from ICT and digital technology.

\section{Digital Inclusion for Empowerment}

As discussed earlier, the deep rooted impact of ICT makes this a serious issue of concern for policy makers all over the world. And especially when it comes to youth that is the population aging between 18-23 years, it is treated as one of the most crucial challenge to be addressed by the policy makers. 


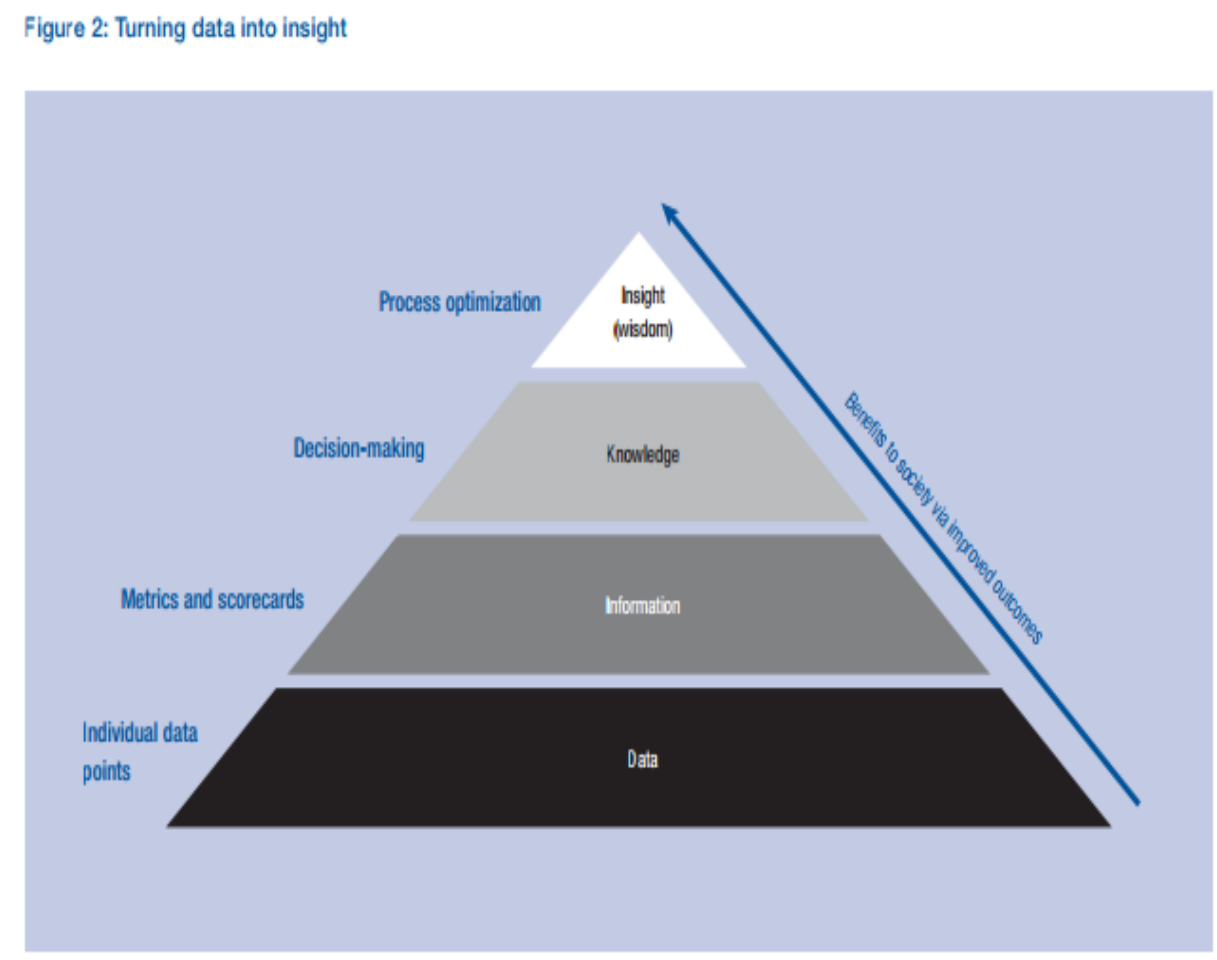

Sources: Ackoff 1989; authors' interpretation.

\section{Figure 1}

Source: http://www3.weforum.org/docs/

WEF_GlobalInformationTechnology_Report_2014.pdf

\section{Impact of Digital Ignorance}

From figure 1 the impact of ICT can be understood. How the access to data when synthesized rationally, gets converted into information. The human mind always try to evaluate the information which leads to knowledge and finally to insight or wisdom.

So through digital inclusion one can develop wisdom or knowledge which is a key component required for economic and social empowerment. And when it is said that youth are untouched by ICT then it becomes a major hurdle in their way for development and empowerment.

\section{Including Youth: Why Is It Important}

Youth are an undervalued but mounting strength on the global stage. Nearly half the world's populace is below the age of 25 and approximately a quarter are aged 12 to 24. Out of those who are aged $12-24$, practically $40 \%$ live on less than two dollars a day. Youth engagement is in crisis according to the ILO, which estimates that some 75 million are unemployed as of 20122 . That accounts for $41 \%$ of over-all worldwide joblessness, and is not expected to recuperate up to beyond 2016.

As youth serve as a base for economic development of any nation, the low employability and skill deficiency may lead into lower rate of economic growth and development of a nation. From the Figure 2 it can be well interpreted that a major chunk of youth population in India is leading to low productivity and low human development indicators which brings the overall performance of nation significantly lower when compared to other nations of the world. 


\begin{tabular}{|c|c|c|c|c|c|c|c|c|c|c|c|c|c|c|}
\hline \multirow[b]{4}{*}{ HOl rank } & \multicolumn{8}{|c|}{ Employment } & \multicolumn{4}{|c|}{ Unemployment } & \multicolumn{2}{|c|}{ Labour productivity } \\
\hline & $\begin{array}{l}\text { Employment } \\
\text { to population } \\
\text { ratioa }\end{array}$ & $\begin{array}{l}\text { labour force } \\
\text { participation } \\
\text { rate" }\end{array}$ & $\begin{array}{c}\text { Employ } \\
\text { agricu }\end{array}$ & $\begin{array}{l}\text { ment in } \\
\text { ulture }\end{array}$ & $\begin{array}{l}\text { Emplop } \\
\text { in sen }\end{array}$ & $\begin{array}{l}\text { yment } \\
\text { vices }\end{array}$ & $\begin{array}{c}\text { labour force } \\
\text { with tertiary } \\
\text { education }\end{array}$ & $\begin{array}{l}\text { Vulnerable } \\
\text { employment }\end{array}$ & Total & Long term & Youth & $\begin{array}{l}\text { Youth not in } \\
\text { school or } \\
\text { employment }\end{array}$ & Output per & $\begin{array}{c}\text { Hours } \\
\text { worked } \\
\text { per week }\end{array}$ \\
\hline & \multicolumn{2}{|c|}{ (\%o ages 15 and older) } & \multicolumn{4}{|c|}{ (\% of total employnent) } & $|\%|$ & $\begin{array}{l}\text { |\% of total } \\
\text { employmentit) }\end{array}$ & \multicolumn{2}{|c|}{ (\% of labour force) } & \multicolumn{2}{|c|}{ (\% ages 15-24) } & $\begin{array}{l}\text { (2005) } \\
\text { Ppp \$) }\end{array}$ & $\begin{array}{l}\text { (peremployed } \\
\text { person) }\end{array}$ \\
\hline & 2013 & 2013 & $1990^{b}$ & $2012^{5}$ & $199 b^{b}$ & $2012^{2}$ & $2007-20122^{d}$ & $2008-2013^{d}$ & 2008-201: & $2008-2013^{4}$ & $2008-2014^{d}$ & $2008-2013^{d}$ & $2005-2012$ & $2003-2012$ \\
\hline 116 Viet Nam & 75.9 & 77.5 &. & 47.4 &. & 31.5 & .. & 62.6 & 2.0 & 0.3 & 6.0 & 9.3 & 5,250 & .. \\
\hline 119 Bolivia (Plurinational State of) & 70.6 & 72.5 & 1.2 & 32.1 & 73.2 & 47.9 & 15.7 & 54.9 & 2.7 & 1.3 & 6.2 & .. & 10,026 & .. \\
\hline 120 Kyrgyzstan & 62.0 & 67.5 & 32.7 & 34.0 & 39.4 & 45.3 & $1.5^{\mathrm{B}}$ & $47.3^{\mathrm{e}}$ & 8.3 & .. & 13.4 & 21.2 & 4,938 & .. \\
\hline 121 Ігаq & 35.5 & 42.3 &. & 23.4 & & 58.3 &. & .. & 15.3 & .. & .. &. & 17,067 & .. \\
\hline 122 Cabo Verde & 62.8 & 67.5 & .. & .. &. & .. & .. & .. & 10.7 & .. & .. & .. & .. & .. \\
\hline 123 Micronesia (Federated States of) &. &. &. &. & &. & .. & .. & .. & .. & .. & .. & .. &. \\
\hline 124 Guyana & 54.5 & 61.4 &. &. &. &. & .. & .. & .. & .. & 24.0 &. & 9,652 & .. \\
\hline 125 Nicaragua & 58.8 & 63.4 & 39.3 & 32.2 & 38.2 & 51.2 & 13.9 & 47.1 & 5.3 & .. & 11.9 &. & 9,043 & 37.4 \\
\hline 126 Morocco & 45.9 & 50.5 & 3.9 & 39.2 & 59.5 & 39.3 & $9.5^{\mathrm{e}}$ & 50.7 & 9.2 & 5.8 & 19.1 &.. & 13,769 & .. \\
\hline 126 Namibia & 49.0 & 59.0 & .. & 27.4 & & 58.7 & $10.8^{\mathrm{e}}$ & 7.8 & 29.6 & 30.9 & 56.2 & 32.0 & 21,086 & .. \\
\hline 128 Guatemala & 65.8 & 67.7 & 12.9 & 32.3 & 57.2 & 48.2 & 7.5 & $49.9^{8}$ & 3.0 & .. & 6.3 & 29.8 & 11,461 & .. \\
\hline 129 Tajikistan & 60.7 & 67.9 &. & 55.5 & & 26.2 &. & 47.1 & 11.5 & .. & 16.7 &.. &. & .. \\
\hline 130 India & 52.2 & 54.2 & .. & 47.2 & .. & 28.1 & .. & 80.8 & 3.6 & 1.4 & 10.7 & .. & 8,821 & .. \\
\hline 131 Honduras & 60.0 & 62.6 & 50.1 & 35.3 & 33.2 & 44.9 & 8.0 & 53.3 & 3.9 & .. & 8.0 & 41.4 & 9,564 & 34.9 \\
\hline
\end{tabular}

Figure 2

Source: http://hdr.undp.org/en/rethinking-work-for-human-development 
In India, the youth population suffers from low levels of education. On average, young people in India receive just over seven years of education. Moreover, there are wide disparities according to caste, class, and gender. For example, the well-off 20 per cent go to eleven years of school, while the deprived quintile be an average of merely four years. The education shortfall is not complete by technical/vocational education and training as only 6 per cent of urban youth and 3 per cent of rural youth attend these organisations at the secondary level.55 (International Youth Foundation, Opportunity for Action: Preparing Youth for 21st Century Livelihoods, 12.)

From Figure 3 it is very much clear that the employment rate of youth in has observed fluctuation in past decades. But still the picture is not very rosy and promising. In order to enhance the economic performance of India; employment of the serves as a key factor on which India needs to thrust.

In India, the youth population suffers from low levels of education. On average, young people in India receive just over seven years of education. Moreover, there are wide disparities according to caste, class, and gender. For example, the wealthiest 20 per cent attend eleven years of school, whereas the poorest quintile averages only four years.54 The education deficit is not filled by technical/vocational education and training as only 6 per cent of urban youth and 3 per cent of rural youth attend these institutions at the secondary level.55 (International Youth Foundation, Opportunity for Action: Preparing Youth for 21st Century Livelihoods, 12.)

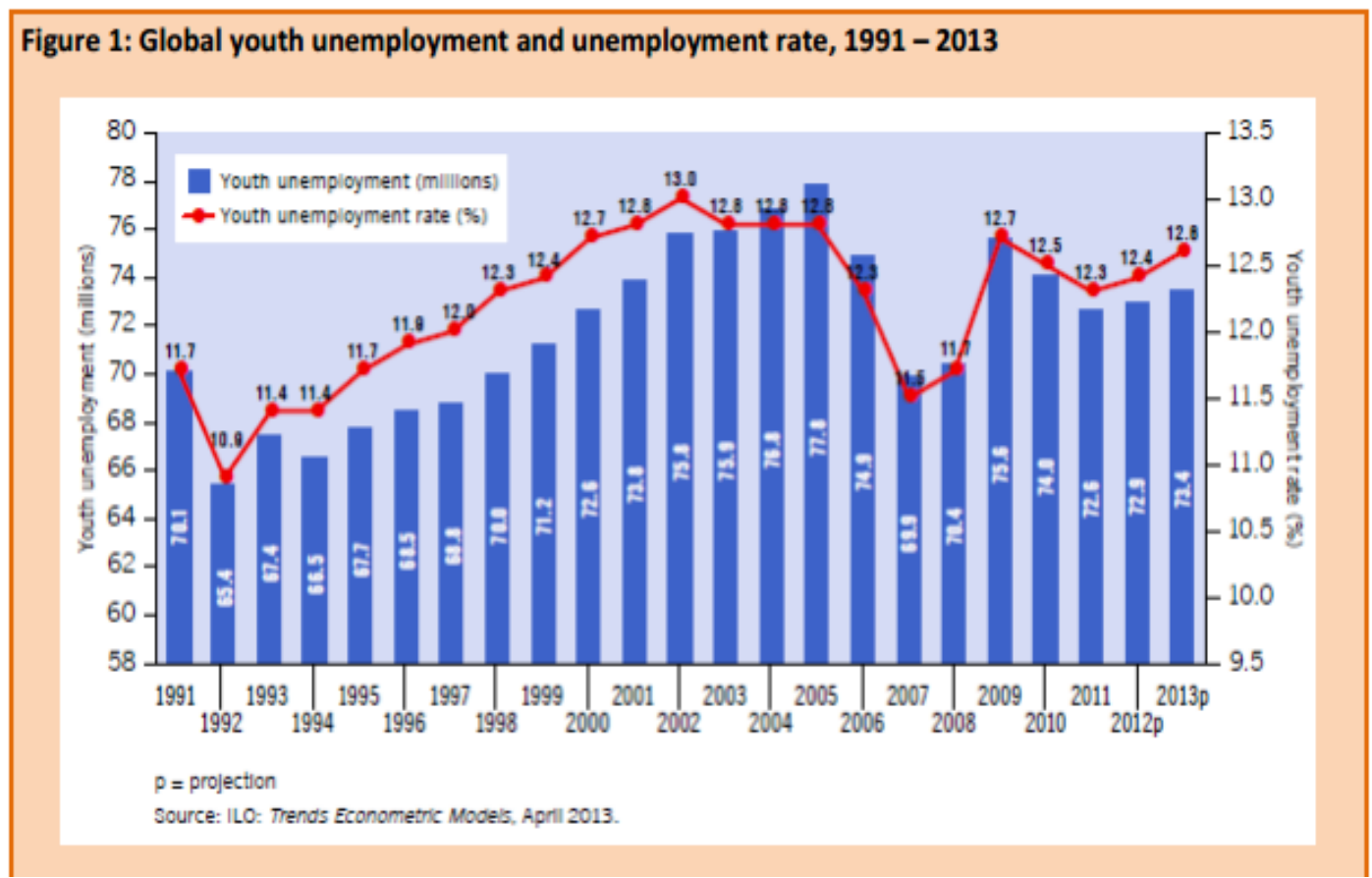

Figure 3

Source: http://www.ilo.org/wcmsp5/groups/public/---dgreports/---dcomm/ documents /publication/wcms_212423.pdf 


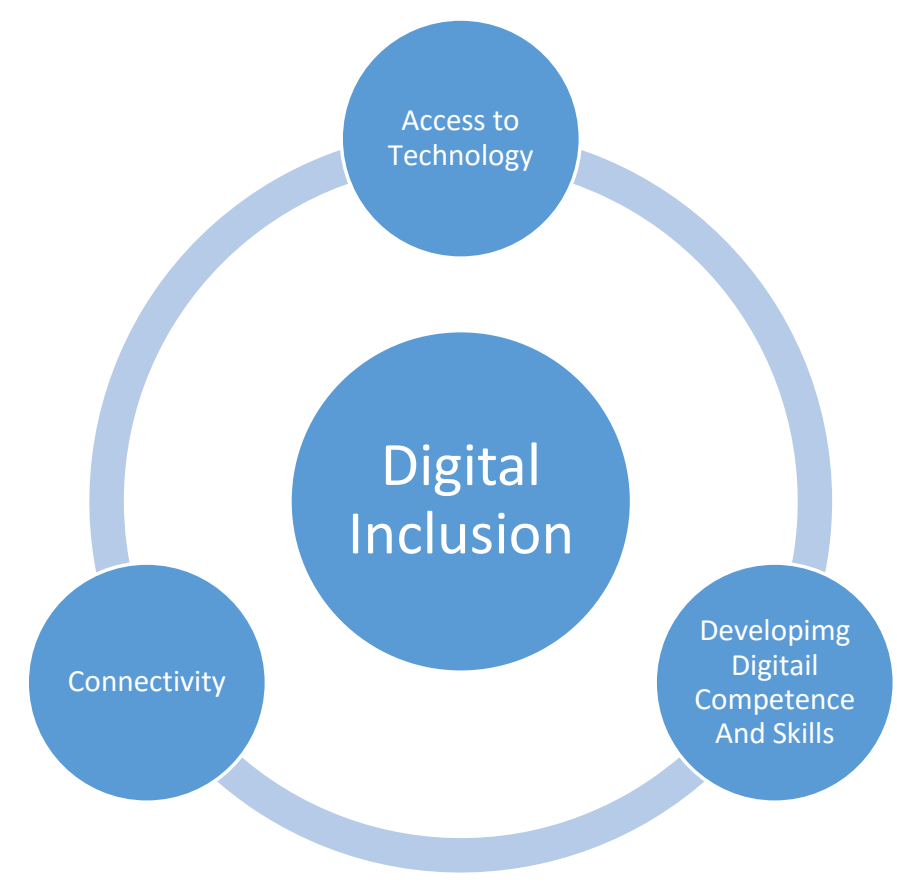

Figure 4- Strategies for Digital Inclusion

\section{The Road Ahead: Strategies for Digital Inclusion}

As report of European Commission 2014 suggests, the three most important reasons for households not having internet access are due Connectivity-lack of infrastructure ((49\%), due to a lack of skills - Digital Skills (37\%) and because of less Access-the equipment (30\%) and access (26\%) costs are too high.

To enhance employability and to raise the economic contribution of youth in terms of income generation it become essentials for Indian government to work on the digital inclusion of youth. As discussed earlier the digital divide needs to be eradicated in order to empower youth digitally. To execute this, a well devised strategic intervention needs to be followed. Which includes the three dimensions Development of Digital Competencies and Skills, Connectivity and Accessibility (figure 4)

\section{- Development of Digital Competencies and Skills}

For digital inclusion one needs proficiency in ICT. And to be proficient in ICT, a person need a different set of technical skill set which is different from behavioural and conceptual set of skills. Digital skill basically mean being capable of using computers and the internet. As lack of digital skills is one of the biggest barriers faced by people which hinders their digital inclusion, it is also considered most important dimension to be worked on.

The fundamental concept of digital inclusion or digital empowerment relies on technical skills development for digital inclusion. So India should work on:

- Extending funding to government and non-government organisations for providing digital skills and support to individuals and SMEs.

- Government should provide Traineeships, Apprenticeships, English and maths; and for all learners to increase their skills, competence and knowledge. It can also launch digital skills initiatives to help offer a range of courses and means of gaining access to the internet to the community.

- Special training programmes for marginalised groups who often serve as heaviest users of the health and care system to use the internet to improve the quality and availability of care. 
- Designing informal training and ongoing support must be done in convenient and friendly locations with trusted Local NGOs.

- To involve people who operate within communities, often specialising in a community of interest and have an ongoing role supporting and advocating for a particular group.

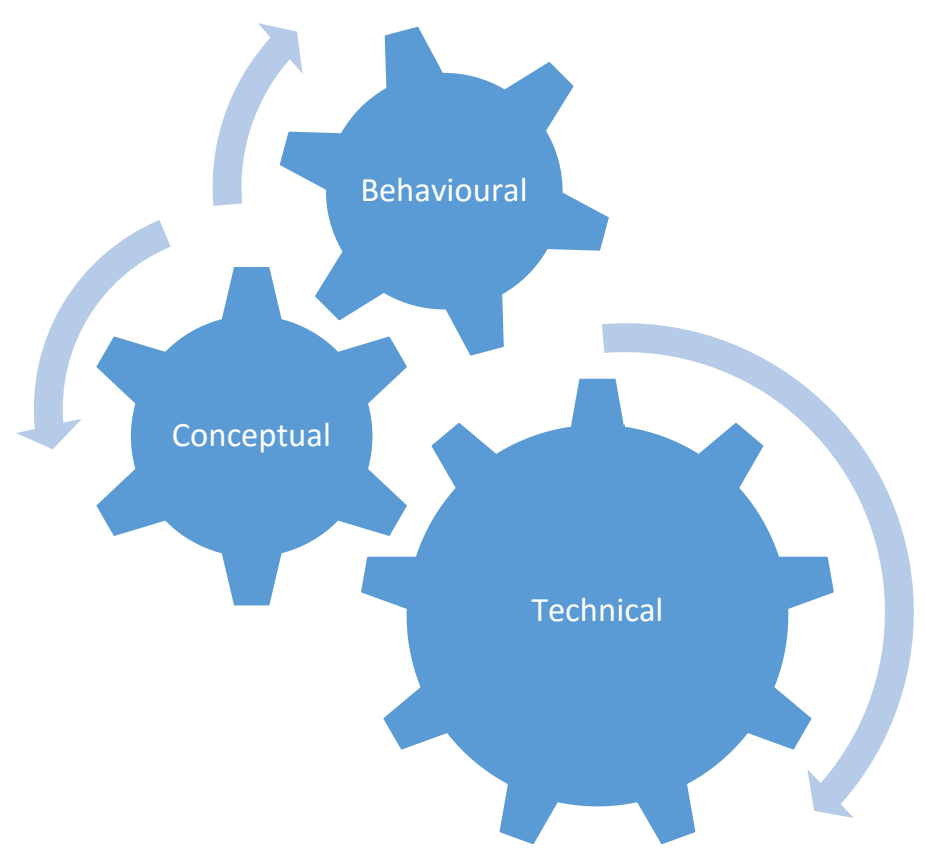

Figure 5- Types of Skills

- Access to Technology: Infrastructure Development

Accessibility emphasises on the services that should be premeditated to encounter all users' requirements, comprising those reliant on assistive technology to access digital services. Obtainability of access is a key blockade for many people, nevertheless digital inclusion is a greatly wider notion and also further than these three dimensions.

The government can take following initiatives to enhance accessibility:

- Provide simple, low cost choices for those who are socially and economically left out to get online access.

- Going online can be confusing, difficult and costly. So make it easy, affordable and simple in with a tailor made customised approach.

- The most digitally omitted are often the most socially and economically debarred, and could value the most from going online. Making the hands-on steps of going online easy and reasonably priced makes a huge transformation to people who are new to the internet.

\section{- Connectivity}

Connectivity this can be understood as access to the internet facility. People need the appropriate infrastructure for that is only the starting point to begin with digital inclusion.

Making internet usage simpler, flawless and quicker for people to discover what they want by fetching these resources collected into one place and superiority promising them by founding various infrastructural amenities and centres which will be inexpensive and manageable to all. Beginning collective programmes with local partners making people who are disconnected conscious of the benefits of going online, and where to go for support. The strategies can be: 
- Finding ways of value assuring digital inclusion maintenance

- Backing and providing digital expertise, to ensure it supports the needs of individuals and a clear attitude to digital provision for SMEs.

\section{Cases of Digital Inclusion Campaigns}

The Ministry of Information and Communications Technology (ICTQATAR)

ICTQATAR has devised a strategy to bridge the digital divide in Qatar involve everybody to be a part of Qatar's information society through its Digital Inclusion campaign which is a procedure of bringing access to the Qatar population who are presently deficient of technological and IT skills. The intention is to deliver access to basic technologies, and infusion of skills to use technology, leading to empowerment of the nation.

In order to expedite this, in 2014 ICTQATAR has established a Digital Inclusion Strategy, "Bridging the Digital Divide" that reaches all segments of the community through a prudently well-thought-out program of awareness, access, training and maintenance.

Significant principles of ICTQATAR's Digital Inclusion Strategy:

- Delivery methodology should be appropriate for each target group and work program

- Taking care of literacy levels and requirements of each target group

- Consideration of cultural matters

- Contextualize consciousness and training programs

- Deliver suitable and relevant content and support

- Work in corporation with shareholders and capacity build where essential

- Conduct continuing investigation of needs and barriers, as well as appraise and gauge initiatives

\section{Government of UK}

The government and Go ON UK, the digital skills charity, have together led a crosssector conglomerate engrossed on conveying these actions that mean, by 2016, to reduce the number of people who are disconnected by $25 \%$. And they have planned to carry on to do this every 2 years. They visualise that by 2020 everyone who can be digitally proficient, will be. To support people go connected and benefit from the internet, the Digital Inclusion Strategy focuses on:

- discontinuing movement that adds little or no value, comprising of disjointed government spending

- providing superior backing to those initiatives and organisations that make a difference

- crafting the background for better, sturdier joint working between people, business, donations and public sector

\section{Scottish Government}

The Glasgow Housing Association (GHA), Scottish Government and BT have amalgamated together to deliver inexpensive broadband to a tower block in central Glasgow. As only $37 \%$ of those people living in social housing being online, support through housing providers is enormously significant. 


\section{Conclusion}

These strategies and cases cited in the above text are just a part of beginning of digital inclusion campaign. There are many more challenging areas in the field which need much thrust. A lot is required to be to help people and organisations gain access to the internet and develop the skills, motivation and trust in order to make people digitally competent and confident.

Though the challenges that are hindering the effective digital inclusion of individuals and organizations will continue to change and accordingly government should work in the direction of building resilient, better partnerships, operating collected, to support people and organisations benefit from the internet and ICT.

\section{References}

- CIA World Fact book and US Global Population Census figures.

- http://www.bioscience.heacademy.ac.uk/resources/entrepreneurship/skills.asp $\underline{x}$

- http://www.brookings.edu/ /media/research/files/reports/2015/08/financialdigital-inclusion-20 15-villasenor-west-lewis/fdip2015.pdf

- http://www.gha.org.uk/content/default.asp?page=s25_1\&newsid=4239\&back $=\mathrm{s} 25$

- http://www.ictqatar.qa/en/digital-society/digital-inclusion

- http://www.itu.int/net/pressoffice/press_releases/2014/23.aspx\#.VDKPgfldV 9y accessed on 23-06-2015

- http://www.iyfnet.org/sites/default/files/Opportunity for Action.pdf

- http://www3.weforum.org/docs/WEF GlobalInformationTechnology Report 2014.pdf

- https://www.gov.uk/government/publications/government-digital-inclusionstrategy/government-digital-inclusion-strategy

- ILO World of Work Report 2012: Better Jobs for a better economy. Retrieved from http://www.ilo. org/global/research/global-reports/world-ofwork/WCMS 179453/lang--en/index.htm) accessed on 12-05-2015

- ILO. The youth employment crisis: A call for action retrieved from http://www.ilo.org/ Washington / WCMS_185950/lang--en/index.htm accessed on 22-03-2015

- International Labour Organization, "Global Employment Trends for Youth 2013," as retrieved from http://www.ilo.org/wcmsp5/groups/public/--dgreports/---dcomm/documents/publication/wcms_212423.pdf accessed on $\underline{\text { 21-12-2015 }}$

- McKinsey \& Company, The Impact of the Internet on Economic Growth and Prosperity, 2011

- Weil, M. M., \& Rosen, L. D. (1995). The psychological impact of technology from a global perspective: A study of technological sophistication and technophobia in university students from twenty-three countries. Computers in Human Behavior, 11(1), 95-133.

- World Bank, World Development Report 2013: Jobs (Washington, D.C.: World Bank, 2012), DOI: 10.1596/978-0-8213- 9575-2. 